\title{
Effect of rate of change of luteinizing hormone concentration on in-vitro progesterone secretion within rat corpora lutea during differentiation
}

\author{
J. C. Nulsen, J. Sullivan and J. J. Peluso \\ Department of Obstetrics and Gynecology, University of Connecticut Health Center, Farmington, \\ CT 06032, USA
}

\begin{abstract}
Summary. Immature rats were injected with pregnant mares' serum gonadotrophin followed by human chorionic gonadotrophin (hCG). Ovaries were removed $0,2,5$ or 8 days after hCG and either prepared for morphometric analysis or perifused with 0,5 or $30 \mathrm{ng}$ luteinizing hormone $(\mathrm{LH}) / \mathrm{min}$. In a second study, ovaries were removed on Day 2 or 8 and perifused with $0.1 \mathrm{mg} 8$-br-cyclic adenosine $5^{\prime}$-phosphate $/ \mathrm{ml}$ ( 8 -br-cAMP). On Day 0 , the granulosa cells of the preovulatory follicles were small $\left(53 \pm 0.5 \mu \mathrm{m}^{2}\right)$ with a cytoplasmic to nuclear $(\mathrm{Cy}: \mathrm{Nu})$ ratio $\leqslant 1 \cdot 5$. By Day 2 , corpora lutea $(\mathrm{CL})$ were present and composed of $95 \%$ small luteal cells (diameter $<125 \mu \mathrm{m}^{2}, \mathrm{Cy}: \mathrm{Nu} \geqslant 3 \cdot 0$ ) and $5 \%$ large luteal cells (diameter $>125 \mu \mathrm{m}^{2}, \mathrm{Cy}: \mathrm{Nu}$ ratio $\geqslant 3.0$ ). The percentage of large luteal cells increased to $36 \pm 7 \%$ by Day 5 , suggesting that they are derived from a select population of small luteal cells. Basal progesterone secretion increased from $38 \pm 5$ on Day 0 to $1010 \pm 48 \mathrm{pg} / \mathrm{mg} / \mathrm{ml}$ on Day 8 . The rate of $5 \mathrm{ng} \mathrm{LH} / \mathrm{min}$ stimulated progesterone secretion on Days 0,2 and $8 ; 30 \mathrm{ng} \mathrm{LH} / \mathrm{min}$ stimulated progesterone secretion on Days 0,2 and 8, but not on Day 5; 8-br-cAMP stimulated progesterone secretion on both Days 2 and 8 . These data demonstrate that once granulosa cells are induced to luteinize they lose their capacity to secrete progesterone in response to $5 \mathrm{ng}$ $\mathrm{LH} / \mathrm{min}$ and do not regain their responsiveness to $\mathrm{LH}$ rate until they completely differentiate. The loss of this $\mathrm{LH}$ responsiveness appears to be due to an inability to stimulate sufficient intracellular cAMP concentrations, since cAMP stimulates progesterone secretion on both Days 2 and 8.
\end{abstract}

Keywords: luteinizing hormone; progesterone; corpus luteum; rat

\section{Introduction}

The mature corpus luteum in rats is a complex structure composed of small and large luteal cells (Smith et al., 1989). Although the origin of these luteal cells is not clear, large luteal cells are thought to differentiate from the granulosa cells of the preovulatory follicle and small luteal cells from thecal cells (Niswender et al., 1985). Both sizes of rat luteal cells have ultrastructural features of steroidogenic cells, possess aromatase activity and luteinizing hormone (LH) receptors and secrete progesterone in response to $\mathrm{LH}$ and/or cyclic adenosine $5^{\prime}$ phosphate (cAMP) (Smith et al., 1989). The major difference between large and small rat luteal cells is that the larger cells have a higher basal progesterone secretion rate due in part to a twofold increase in the expression of the mRNA which encodes for the cytochrome P-450 side-chain cleavage (scc) enzyme that converts cholesterol to pregnenolone (Gibori et al., 1988).

The exact role that $\mathrm{LH}$ plays in the development of both sizes of luteal cells remains to be determined. It is clear that granulosa cells luteinize in response to the LH surge, which sets off a cascade of biochemical and morphological events that result in the mobilization of cholesterol, the 
reorganization of endosomes, lysosomes and lipid droplets and structural changes in the mitochondria and smooth endoplasmic reticulum (Amsterdam et al., 1989). In the final stages of luteinization, the shape of the cells changes such that the cytoplasmic to nuclear (Cy: $\mathrm{Nu})$ ratio increases. The LH surge also stimulated the expression of the cytochrome P-450 scc mRNA, which is constitutively expressed throughout the life of the luteal cell (Goldring et al., 1987), and activity of cytochrome P-450 17 $\alpha$ dehydrogenase, which converts progesterone into androstenedione. Androstenedione is then aromatized within the luteal cell to oestradiol, which is luteotrophic (Gibori et al., 1988).

Luteinizing hormone initially down-regulates its own receptor then gradually increases the number of $\mathrm{LH}$ receptors/cell, the number of $\mathrm{LH}$ receptors peaking by 5 days after administration of human chorionic gonadotrophin, and progesterone secretion mirroring that of the induction of the LH receptors (Rajaniemi et al., 1977). Since the number of LH receptors increases with luteal cell development in vivo and LH stimulates progesterone secretion in vitro (Wu \& Wiest, 1978; Shiota \& Wiest, 1979), LH appears to play an essential role in regulating progesterone secretion from the developing corpora lutea (CL). However, in an intact animal, LH is secreted in discrete pulses (Gallo, 1981; Gallo et al., 1985), the rate at which a 'threshold' amplitude is obtained (i.e. slope) playing a dominant role in determining whether an LH pulse will stimulate ovarian steroid secretion (Peluso \& Steger 1987; Nulsen et al., 1991). Therefore, if LH is important in controlling luteal cell function, luteal cells must be capable of responding to LH slopes which mimic those of intact animals. The present experiments were designed to determine the ability of $\mathrm{CL}$ at various stages of development to secret progesterone in respone to different rates of LH secretion.

\section{Materials and Methods}

Preparation of culture medium. Ovine luteinizing hormone (NIAMDDK-oLH-26) was used in these experiments. A stock solution was prepared by dissolving $10 \mathrm{mg}$ oLH in $10 \mathrm{ml}$ of phosphate-buffered saline and then storing $500 \mu \mathrm{l}$ aliquots at $-20^{\circ} \mathrm{C}$ for up to 3 months. oLH was added to Ham's F-10 supplemented with $2.64 \mathrm{~g}$ Hepes $/ 1,2.34 \mathrm{~g}$ $\mathrm{NaHCO}_{3} / 1,110 \mathrm{mg}$ calcium lactate $/ \mathrm{l}, 245 \mathrm{mg}$ sodium pyruvate $/ 1,50 \mathrm{mg}$ streptomycin sulphate $/ 1,60 \mathrm{mg}$ penicillin$\mathrm{G} / \mathrm{ml}, 10 \%$ fetal calf serum and insulin $(200 \mathrm{iu} / \mathrm{l}$; Lente Iletin I, Eli Lilly, Indianapolis, IN, USA). The pH of the medium was adjusted to $7 \cdot 4$.

Animals. Immature (21-day-old) female Wistar rats were obtained from Charles River Laboratory and housed

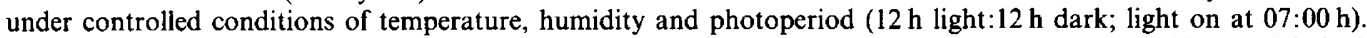
When the rats were 30-34 days old, they were injected with 20 iu pregnant mares' serum gonadotrophin (PMSG, i.p.) between 09:00 and 12:00 h; $48 \mathrm{~h}$ after PMSG, some rats were injected with I0 iu of human chorionic gonadotrophin (hCG, i.p.). Rats were autopsied on $0,2,5$ or 8 days after hCG. The ovaries were removed, trimmed of fat and either processed for morphometric analysis or placed in culture.

Morphometric analysis. To assess the cell composition of the $\mathrm{CL}$ at different stages of development, ovaries were fixed in formalin, dehydrated, embedded in paraffin wax, sectioned at $10 \mu \mathrm{m}$ and stained with haematoxylin and eosin. For each day, 100 cells from each of 5 follicles or $\mathrm{CL}$ were analysed. To ensure that these 100 cells represented the overall cell population, groups of 25 cells were analysed from areas marked by the perpendicular axes of each structure. The perimeter of each individual cell and its nucleus were traced using an image analyser (Image Technology, Deer Park, NY, USA) and from these measurements total cell area, nuclear area, cytoplasmic area and Cy:Nu ratio were calculated.

Perifusion experiments. At autopsy the ovaries were removed, trimmed of fat, placed in heparinized culture medium ( $3 \mu \mathrm{g}$ heparin $/ \mathrm{ml})$ and dissected into fragments, each fragment weighing $10-15 \mathrm{mg}$. Each tissue fragment was then placed in perifusion culture as described by Peluso et al. (1984) except for the following modifications. Millipore filter holders ( $\$ 5 X 0001300$, Millipore Corporation, Bedford, MA, USA) with a volume of $200 \mu \mathrm{l}$ were used as culture chambers, which were placed in a waterbath maintained at $37^{\circ} \mathrm{C}$ during perifusion and the medium flow rate was set at $1.7 \mathrm{ml} / \mathrm{h}$. The medium was continuously gassed with $5 \% \mathrm{CO}_{2}$ in oxygen throughout the perifusion period. In these experiments, the ovarian tissue was perifused with control medium for $2 \mathrm{~h}$ then exposed to either control medium or one of two LH treatments. These treatments differed in that the ascending slope was either $5 \mathrm{ng} / \mathrm{min}$ or $30 \mathrm{ng} / \mathrm{min}$; the time required to achieve the final amplitude of $250 \mathrm{ng} / \mathrm{ml}$ was 50 and $8 \mathrm{~min}$, respectively. After obtaining a concentration of $250 \mathrm{ng} / \mathrm{ml}$, this $\mathrm{LH}$ concentration was maintained for the remainder of the perifusion culture. Perifusates were collected at $1-\mathrm{h}$ intervals, frozen and stored at $-20^{\circ} \mathrm{C}$ until assayed for progesterone. In a second series of experiments, ovarian tissue was collected on Days 2 and 8 , perifused with control medium for $2 \mathrm{~h}$ and then exposed to either control medium or 8 -br-cAMP $(0 \cdot 1 \mathrm{mg} / \mathrm{ml})$. 
Progesterone assay. The progesterone content in the media was determined using a solid-phase radioimmunoassay (ICN Biomedicals, Inc., Carson, CA, USA). The antiserum to progesterone cross-reacts $100 \%$ with progesterone, $4.3 \%$ with $20 \alpha$-dihydroprogesterone and $<0.01 \%$ with several other steroids. The assay sensitivity was $0.5 \mathrm{ng} / \mathrm{ml}$ with intra- and interassay coefficients of variation of $7 \cdot 4$ and $10 \cdot 5 \%$, respectively.

Statistical analysis. When appropriate, the results were presented as the mean \pm 1 s.e.m. Since basal progesterone secretion rate increases as luteal cells differentiate, progesterone values were expressed as a percentage of the basal secretion rate in order to compare the responses to LH slopes. The data were analysed using either a two-way or oneway ANOVA followed by the Student-Newman-Keuls multiple range test. For all experiments, results were considered statistically significant when $P$ was $\leqslant 0.05$.

\section{Results}

On Day 0 the ovary contained numerous preovulatory follicles $>500 \mu \mathrm{m}$ in diameter. The granulosa cells of these follicles were unimodally distributed around a mean area of $53 \pm 0.5 \mu \mathrm{m}^{2}$ and a $\mathrm{Cy}: \mathrm{Nu}$ ratio of $\leqslant 1 \cdot 5$. Forty-eight $\mathrm{h}$ after $\mathrm{hCG}$, the principal structures within the ovary were $\mathrm{CL}$. The average area of the cells which composed these CL was $95 \pm 1 \mu \mathrm{m}^{2}$. These luteal cells were
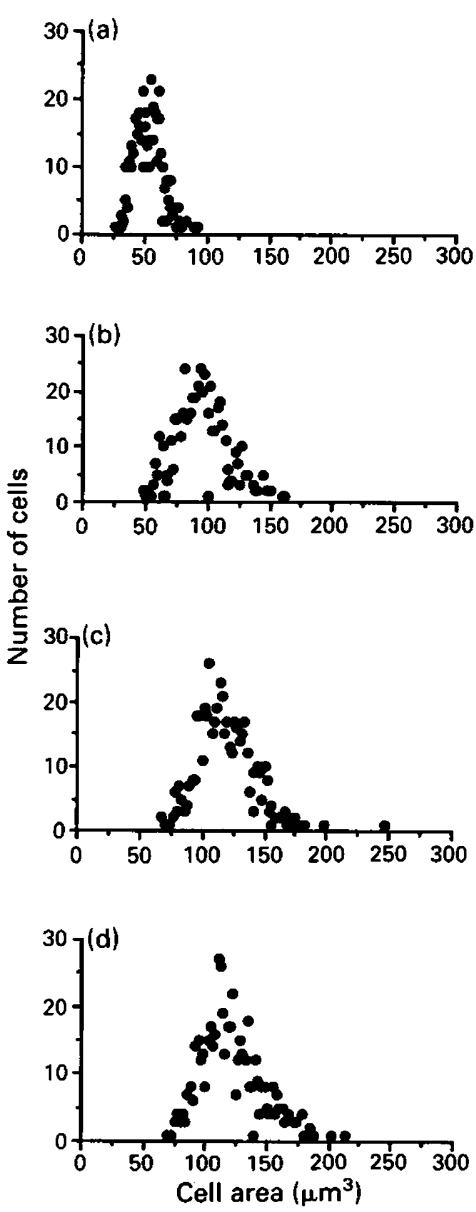

Fig. 1. The frequency and size distribution of individual cells of rat follicles or corpora lutea (CL) at (a) 0, (b) 2, (c) 5 and (d) 8 days after treatment with human chorionic gonadotrophin. On each day, 5 follicles or CL were analysed; 100 cells from each follicle or CL were measured with the aid of a computer-controlled image analyser. 


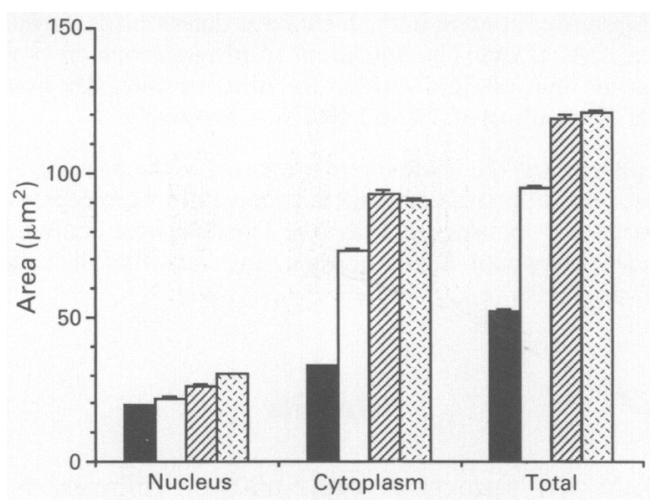

Fig. 2. Changes in the nuclear, cytoplasmic and total cell area of the cells comprising rat follicles or corpora lutea on $0(\square), 2(\square), 5(\square)$ and 8 days (国) after hCG treatment. Data are means \pm 1 s.e.

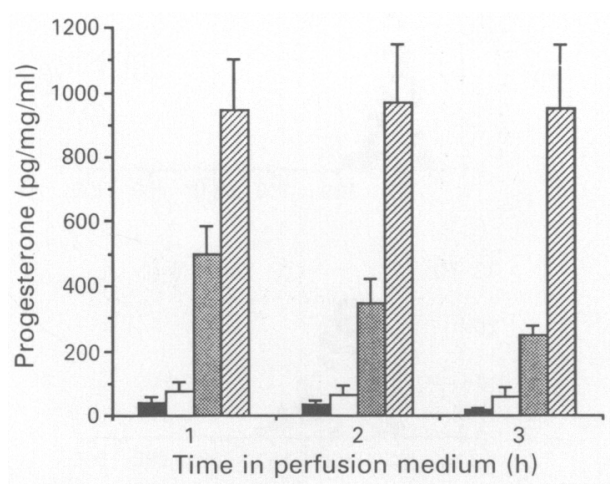

Fig. 3. Effect of human chorionic gonadotrophin (hCG) on basal progesterone secretion in rats. Ovaries were removed after $0(\square), 2(\square), 5(叉)$ and 8 days (ख्र) after hCG and placed in perifusion culture. The ovarian fragments were perifused with control medium at $1.7 \mathrm{ml} / \mathrm{h}$. Medium was collected in hourly fractions and assayed for progesterone content, $n=6-12 /$ group. Progesterone values are presented for the last $3 \mathrm{~h}$ of perifusion. Data are means \pm 1 s.e.

larger $(P<0.05)$ than granulosa cells of the follicles; the increase in cell size was mainly due to an increase in cytoplasm resulting in a $\mathrm{Cy}: \mathrm{Nu}$ ratio of $\geqslant 3.0$. The cell size distribution on Day 2 was skewed to the right (Fig. 1), 95\% of the cells being $<125 \mu \mathrm{m}^{2}$. Therefore, cells that had a $\mathrm{Cy}: \mathrm{Nu}$ ratio $\geqslant 3.0$ and were $<125 \mu \mathrm{m}^{2}$ were considered small luteal cells and those with a $\mathrm{Cy}$ : $\mathrm{Nu}$ ratio $\geqslant 3.0$ and $>125 \mu \mathrm{m}^{2}$ were classified as large luteal cells. On Day 5 the mean cell area increased to $119 \pm 1 \mu \mathrm{m}^{2}$ because of hypertrophy of the cytoplasm. The size distribution remained skewed to the right (Fig. 1), some of the cells reaching 175-200 $\mu^{2}{ }^{2}$. Large luteal cells comprised $36 \pm 7 \%$ of the CL on Day 5. On Day 8 the size, Cy: Nu ratio, distribution pattern and the percentage of large luteal cells were similar to that observed on Day 5 (Figs 1 and 2).

When ovarian fragments were perifused with control medium, progesterone secretion increased from Day 0 to Day 8 (Fig. 3). Although the basal rate of progesterone secretion on Day 0 was low, both 5 and $30 \mathrm{ng} \mathrm{LH} / \mathrm{min}$ stimulated progesterone secretion (Fig. 4). On Day 2, the $5 \mathrm{ng} \mathrm{LH} / \mathrm{min}$ increased progesterone secretion during the second hour of exposure, but the $30 \mathrm{ng} \mathrm{LH} / \mathrm{min}$ enhanced progesterone secretion throughout the culture period (Fig. 4). On Day 5, neither the 5 

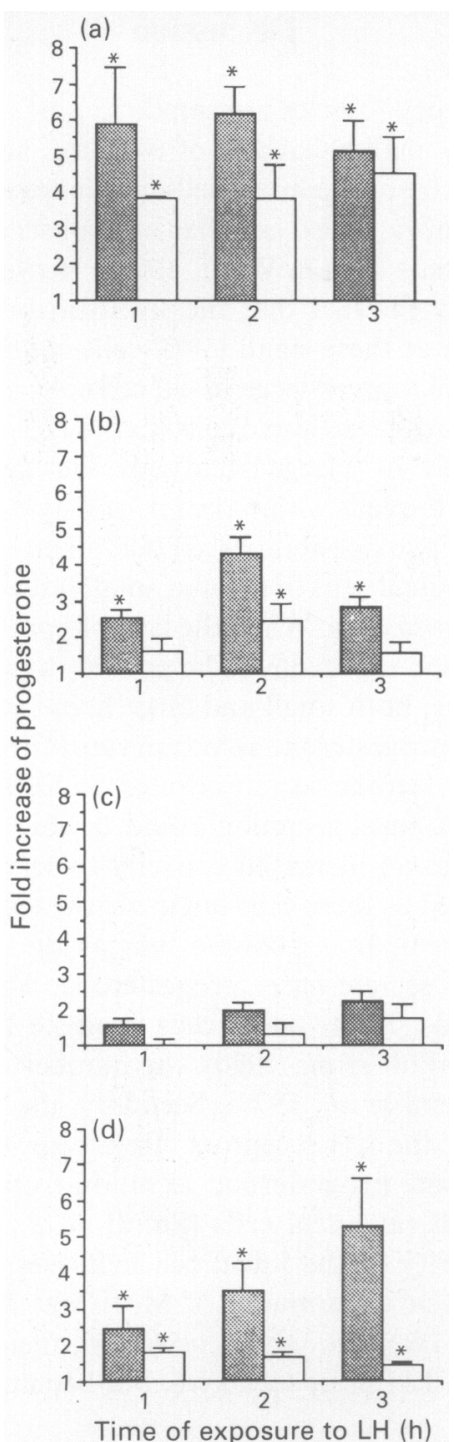

Fig. 4. Effect of rate of luteinizing hormone (LH) exposure on progesterone secretion from ovarian tissue isolated from immature rats primed with pregnant mares' serum gonadotrophin and human chorionic gonadotrophin (hCG). The ovarian fragments were collected at (a) 0 , (b) 2, (c) 5 and (d) 8 days after hCG and perifused with control medium during the pre-test (the first $2 \mathrm{~h}$ ) and then with $5(\square)$ or 30 (圈) $\mathrm{ng} / \mathrm{min}$ until a concentration of $250 \mathrm{ng} \mathrm{LH} / \mathrm{ml}$ was obtained. Progesterone secretion for the last $3 \mathrm{~h}$ of perifusion was expressed as a fold increase of the respective control values. Differences between treatment groups in this and subsequent studies were analysed by a one-way ANOva followed by Student-Newman-Keuls multiple range test; *significantly greater than control values $(P<0.05), n=6-12 /$ group. Data are means \pm 1 s.e.

nor $30 \mathrm{ng} \mathrm{LH/min} \mathrm{stimulated} \mathrm{progesterone} \mathrm{secretion} \mathrm{(Fig.} \mathrm{4),} \mathrm{but} \mathrm{on} \mathrm{Day} \mathrm{8,} \mathrm{both} \mathrm{LH} \mathrm{rates} \mathrm{stimu-}$ lated progesterone secretion over basal concentrations (Fig. 4). When luteal tissue isolated on Days 2 and 8 was perifused with 8 -br-cAMP, progesterone secretion was $3.9 \pm 0.8$ and $2.5 \pm 0.9$ times greater than in the controls on Days $2(P<0.05)$ and $8(P<0.05)$, respectively. 


\section{Discussion}

The granulosa cells of preovulatory follicles are small $\left(53 \mu \mathrm{m}^{2}\right)$ and have a $\mathrm{Cy}: \mathrm{Nu}$ ratio of $\leqslant 1 \cdot 5$. Granulosa cells differentiate into small luteal cells of $\sim 95 \mu \mathrm{m}^{2}$ and a $\mathrm{Cy}: \mathrm{Nu}$ ratio $\geqslant 3.0$ within $48 \mathrm{~h}$ of hCG treatment. The average size of the luteal cells continues to increase over the next $72 \mathrm{~h}$ (Day 5). A similar increase in the size of rat luteal cells has been observed during the corresponding days of pseudopregnancy and pregnancy (Wu \& Wiest, 1978). However, not all small luteal cells continue to enlarge, as indicated by the fact that the size distribution is skewed to the right. This suggests that a select population of these small luteal cells continue to hypertrophy over the next several days giving rise to a population of large luteal cells. As a result, the composition of the CL changes such that the percentage of large luteal cells (i.e. $\geqslant 125 \mu \mathrm{m}^{2}$ ) gradually increases until Day 5 when the CL are composed of 30-40\% large luteal cells. This agrees with the results of Smith et al. (1989), who showed that $46 \%$ of the cells within the CL of Day- 8 pregnant rats are large luteal cells. The above data support either of two possibilities: (i) that all luteal cells are of granulosa cell origin, only some developing into large luteal cells or (ii) that small luteal cells are derived from thecal cells, and large luteal cells from granulosa cells. While the latter hypothesis appears to be true for bovine luteal cells (Niswender et al., 1985), it remains to be proved in rats.

While luteal cells differ in size, both small and large luteal cells secrete progesterone, the large luteal cells having a higher basal progesterone secretion rate (Gibori et al., 1988; Smith et al., 1989). In the present study, basal progesterone secretion rates on Days 5 and 8 are 12-20 times greater than on Day 2. This increase in basal secretion could be due to the increase in the percentage of large luteal cells which possess an increased capacity to secrete progesterone. Although basal progesterone secretion is increased as these cells luteinize, the factors responsible for this enhanced luteal cell function are not known. It is possible that as the cells luteinize they become more responsive to $\mathrm{LH}$ and therefore secrete more progesterone. This concept is supported by three sets of experimental observations. First, luteal cells produce large quantities of mRNA which encode for the LH receptors (LaPolt et al., 1990), the number of LH receptors/cell increasing as luteinization progresses (Rajaniemi et al., 1977). Secondly, the pattern of progesterone secretion mirrors that of the induction of the LH receptors (Rajaniemi et al., 1977). Finally, the concentration of $\mathrm{LH}$ required to stimulate progesterone secretion from large rat luteal cells is ten times less than that required for small rat luteal cells (Smith et al., 1989). While these experimental findings suggest that the sensitivity of the luteal cell increases during luteinization, this conclusion is not supported by the classic experiments of Morishige \& Rothchild (1974) in which antisera to LH was administered to rats throughout gestation; their studies clearly demonstrate that luteal function is independent of LH prior to Day 6, but becomes dependent on LH by Day 8 of pregnancy.

To resolve this controversy, Wiest and associates have attempted to assess luteal cell responsiveness to LH in vitro: luteal cells were perifused with constant stimulatory doses of LH. Under these conditions LH stimulates luteal cells isolated on Days 2 (Wu et al., 1976), and 4 (Shiota \& Wiest, 1979) of pregnancy to secrete progesterone. Similarly, the present data demonstrate that luteal tissue isolated from Days 2 and 8 secretes progesterone in response to the $30 \mathrm{ng} \mathrm{LH} / \mathrm{min}$. However, in intact animals, $\mathrm{LH}$ is not secreted in a tonic fashion, but in discrete pulses of $\sim 5 \mathrm{ng} / \mathrm{min}$ (Gallo $\mathrm{et}$ al., 1985). As luteal cells differentiate, their ability to respond to a $5 \mathrm{ng} \mathrm{LH} / \mathrm{min}$ gradually decreases and is lost by Day 5. For a cell to respond to the pulsatile pattern of serum $\mathrm{LH}$ it must be sensitive to this physiological LH rate. Our data indicate that as luteal cells differentiate they lose the ability to respond to the pulsatile pattern of serum LH, while differentiated luteal cells (i.e. Day 8 ) are sensitive to pulsatile LH. These data support the concept that the increase in basal progesterone secretion is not dependent on continuous $\mathrm{LH}$ stimulation. These proposed changes in sensitivity to LH secretion rate which occur during luteal cell differentiation, also explain why the injection of antiserum to $\mathrm{LH}$ into intact rats during the first 6 days of pregnancy does not influence luteal function, but does result in luteolysis after Day 8 (Morishige \& Rothchild, 1974). 
Although differentiating luteal cells are insensitive to a physiologically relevant LH secretion rate, these cells produce large quantities of mRNA, which encode for the LH receptors (LaPolt $e t$ al., 1990) and possess numerous LH receptors which can be localized on their surface membranes (Rajaniemi et al., 1977). Further, cAMP analogues stimulate an increase of similar magnitude in progesterone secretion from both Day-2 and Day-8 CL (present data). This suggests that, while the number of LH receptors increases during luteal differentiation, they are not efficiently coupled to the adenylate cyclase system until luteinization is complete. This concept is consistent with the data of Hunzicker-Dunn \& Birnbaumer (1976), who showed that, although large doses of LH can increase adenylate cyclase activity in developing $\mathrm{CL}$, maximum $\mathrm{LH}$-induced adenylate cyclase activity is not observed until 7 days after hCG. McLean et al. (1990) have identified a 32k protein which is selectively expressed in large luteal cells and not in follicle (granulosa) cells. The expression of this protein is enhanced by LH (hCG) and is endogenously phosphorylated, suggesting that this protein is involved in mediating the action of $\mathrm{LH}$. Whether this or other proteins are involved in coupling the $\mathrm{LH}$ receptor-adenylate cyclase system and subsequent development of luteal cell sensitivity to $\mathrm{LH}$ secretion rate remains to be determined.

The authors thank A. Pappalardo and S. Kavel for their excellent technical assistance and NIAMDD for the gift of LH. This work was supported in part by a grant from the University of Connecticut Research Foundation.

\section{References}

Amsterdam, A., Rotmensch, S. \& Ben-Ze'ev, A. (1989) Coordinated regulation of morphological and biochemical differentiation in a steroidogenic cell: the granulosa cell model. TIBS 14, $376-382$.

Gallo, R.V. (1981) Pulsatile LH release during periods of low level LH secretion in the rat estrous cycle. Biol. Reprod. 24, 771-777.

Gallo, R.V., Devorshak-Harvey, E. \& Bona-Gallo, A. (1985) Pulsatile luteinizing hormone release during pregnancy in the rat. Endocrinology 116, 2637-2642.

Gibori, G., Khan, I., Warshaw, M.L., McLean, M.P., Puryear, T.K., Nelson, S., Durkee, T.J., Azhar, S., Steinchneider, A. \& Rao, M.C. (1988) Placentalderived regulators and the complex control of luteal cell function. Recent Prog. Hor. Res. 44, 377-429.

Goldring, N.B., Durica, J.M., Lifka, J., Hedin, L., Ratoosh, S.L., Miller, W.L., Orly, J. \& Richards, J.S. (1987) Cholesterol side-chain cleavage P450 messenger ribonucleic acid: evidence for hormonal regulation in rat ovarian follicles and constitutive expression in corpora lutea. Endocrinology 120, $1942-1950$.

Hunzicker-Dunn, M. \& Birnbaumer, L. (1976) Adenylyl cyclase activities in ovarian tissues. III. Regulation of responsiveness to $\mathrm{LH}, \mathrm{FSH}$, and $\mathrm{PGE}_{1}$ in the prepubertal, cycling, pregnant, and pseudopregnant rat. Endocrinology 99, 198-210.

LaPolt, P.S., Oikawa, M., Jia, X.C., Dargan, C. \& Hsueh, A.J.W. (1990) Gonadotropin-induced upand down-regulation of rat ovarian $\mathrm{LH}$ receptor message levels during follicular growth, ovulation and luteinization. Endocrinology 126, 3277-3279.

Mclean, M.P., Nelson, S., Parmer, T., Khan, I., Steinschneider, A., Puryear, T. \& Gibori, G. (1990) Identification and characterization of an abundant phosphoprotein specific to the large luteal cell. Endocrinology 126, 1796-1805.

Morishige, W.K. \& Rothchild, I. (1974) Temporal aspects of the regulation of corpus luteum function by luteinizing hormone, prolactin and placental luteotrophin during the first half of pregnancy in the rat. Endocrinology 95, 260-274.

Niswender, G.D., Schwall, R.H., Fitz, T.A., Farin, C.E. \& Sawyer, H.R. (1985) Regulation of luteal function in domestic ruminants: new concepts. Recent Prog. Horm. Res. 41, 101-151.

Nulsen, J.C., Kavel, S. \& Peluso, J.J. (1991) Effect of pulse amplitude of luteinizing hormone, duration and rate of change on progesterone secretion from rat corpora lutea. J. Reprod. Fert. 93, 271-277.

Peluso, J.J. \& Steger, R.W. (1987) Role of LH pulse amplitude and the rate of $\mathrm{LH}$ increase on oestradiol$17 \beta$ secretion by immature rat ovaries in perifusion culture. J. Reprod. Fert. 80, 629-633.

Peluso, J.J., Gruenberg, M.L. \& Steger, R.W. (1984) Regulation of ovarian follicular growth and steroidogenesis by low-amplitude LH pulses. Am. J. Physiol. 246, R 184-R 189.

Rajaniemi, H.J., Midgley, A.R., Jr, Duncan, J.A. \& Reichert, L.E., Jr (1977) Gonadotropin receptors in rat ovarian tissue: III. binding sites for luteinizing hormone and differentiation of granulosa cells to luteal cells. Endocrinology 101, 898-910.

Shiota, K. \& Wiest, W.G. (1979) On the mechanism of prolactin stimulation of steroidogenesis. $A d v$. Exp. Med. Biol. 112, 169-178.

Smith, C.J., Greer, T.B., Banks, T.W. \& Spidaran, R. (1989) The response of large and small luteal cells from the pregnant rat to substrates and secretagogues. Biol. Reprod. 41, I123-1132.

Wu, D.H. \& Wiest, W.G. (1978) A qualitative transition in the luteotropic mechanism of early pregnancy. Endocrinology 103, 513-520.

Wu, D.H., Wiest, W.G. \& Enders, A.C. (1976) Luteotropic regulation of dispersed rat luteal cells in early pregnancy. Endocrinology 98, 1378-1389.

Received 20 August 1990 